\title{
Analysis of the Students' Interactions and Satisfaction During a Collaborative Lab Project
}

\author{
- LEOVY ECHEVERRÍA RODRÍGUEZ ${ }^{1}$ \\ Ruth CoBos PÉREZ ${ }^{2}$ \\ LILIANA MACHUCA-VILLEGAS ${ }^{3}$
}

\section{Abstract}

The main purpose of this paper is to present the students' interactions and satisfaction in a Collaborative Lab Project supported by a Teaching Assistant System-TASystem. The goal of the developed TASystem is twofold: a) to assist the instructors with the design of collaborative learning activities in Learning Management Systems-LMS and b) to help the students when performing this type of activities in these systems. The TASystem was embedded into the LMS Moodle. In order to carry out this study, a research methodology was defined. Students from the School of Engineering at the Universidad del Valle-UNIVALLE (Colombia) took part in the research study. The mainly presented results in this research study showed that the students were motivated to interact and collaborate with their classmates in a small group level. And that most of the students were satisfied when using the TASystem in Moodle.

Keywords: Collaborative learning; Moodle; Student-to-student interactions; Students' satisfaction; TASystem.

\section{Análisis de la satisfacción y las interacciones de los estudiantes durante un Proyecto de Laboratorio Colaborativo}

\section{Resumen}

El principal propósito de este artículo es presentar la satisfacción y las interacciones de los estudiantes en un Proyecto de Laboratorio Colaborativo soportado por un Sistema Asistente de Enseñanza TASystem. El objetivo del

1 Universidad Pontificia Bolivariana, Montería, Colombia.

2 Universidad Autónoma de Madrid, España.

3 Universidad del Valle, Cali, Colombia.

Autor de correspondencia: Echeverría Rodríguez, L. (Leovy): Carrera 6 \# 97A-99, Montería, Córdoba, Colombia. Código postal: 230001. Teléfono: (4) 7860146 - Ext: 161. Correo electrónico: leovy.echeverria@upb.edu.co
Historia del artículo:

Artículo recibido: 16-VIII-2018/ Aprobado: 14-I-2019

Disponible online: 3 de febrero de 2019

Discusión abierta hasta octubre de 2020 
TASystem desarrollado es doble: a) apoyar a los profesores en el diseño de actividades de aprendizaje colaborativo en Sistemas de Gestión de Aprendizaje y b) ayudar a los estudiantes cuando realizan este tipo de actividades en estos sistemas. El TASystem fue integrado en el sistema Moodle. Con el fin de llevar a cabo este estudio, una metodología de investigación fue definida. Los estudiantes de la Escuela de Ingeniería en la Universidad del Valle-UNIVALLE (Colombia) tomaron parte en el estudio de investigación. Los principales resultados presentados en este estudio mostraron que los estudiantes estuvieron motivados a interactuar y colaborar con sus compañeros de clase a nivel de grupos pequeños. $Y$ que la mayoría de los estudiantes estuvieron satisfechos cuando utilizaron el TASystem en Moodle.

Palabras clave: Aprendizaje colaborativo; Moodle; Interacciones estudiante-estudiante; Satisfacción de los estudiantes; TASystem.

\section{Análise da satisfação e as interações dos estudantes durante um Projeto de Laboratório Colaborativo}

\section{Resumo}

O principal proposito deste artigo é apresentar a satisfação e as interações dos estudantes em um Projeto de Laboratório Colaborativo suportado por um Sistema Assistente de Ensino TASystem. O objetivo do TASystem desenvolvido é duplo: a) apoiar aos professores no desenho de atividades de aprendizagem colaborativa em Sistemas de Gerenciamento de Aprendizagem e b) ajudar aos estudantes quando realizam este tipo de atividades nestes sistemas. 0 TASystem foi integrado no sistema Moodle. Com o fim de levar a cabo este estudo, uma metodologia de investigação foi definida. Os estudantes da Escola de Engenharia na Universidade do Valle-UNIVALLE (Colômbia) tomaram parte neste estudo de investigação. Os principais resultados apresentados neste estudo mostraram que os estudantes estiveram motivados a interatuar e colaborar com seus colegas de turma a nível de grupos pequenos. E que a maioria dos estudantes estiveram satisfeitos quando utilizaram o TASystem em Moodle.

Palavras-chave: Aprendizagem colaborativa; Moodle; Interações estudante-estudante; Satisfação dos estudantes; TASystem.

\section{Introduction}

The main objective of this paper is to show a complementary analysis from the study presented in (Echeverría et al., 2017). The mentioned study was carried out at the Universidad del Valle, Colombia. In the experiment participated students from a Programming course taught at the Topographic Engineering Department. They took part in a Collaborative Lab Project.

During the Lab Project the students had to solve a problem associated with a specific topic of Topographic Engineering. The solution was performed by completing collaborative learning activities supported by a Teaching Assistant System called TASystem integrated in the LMS Moodle (www. moodle.org). This assistant has been tested in several courses throughout different universities during the last five years (Echeverría, Cobos and Morales, 2013; Claros et al., 2014; Claros, Echeverria and Cobos, 2015; Echeverría and Cobos, 2015; Echeverria, 2017).

In the mentioned context the current research study emerges. The main objective of this study is to 
analyze the students' interactions and the students satisfaction during the Collaborative Lab Project.

The paper is structured as follows: next, we present the state of the art related to the proposed approach. The third section is a description of the Teaching Assistant System-TASystem. In the fourth section, we explain the research methodology used to perform the research study. The fifth section contains a discussion of the details of the research study and their results. Finally, the paper ends with some conclusions and future research issues (Sixth section).

\section{State of the art}

In this section we present the basis about three relevant topics related to the approach mentioned in this paper: i) Collaborative Learning and Computer Supported Collaborative Learning (CSCL), ii) Learning Management Systems (LMS) highlighting the Moodle system and iii) Teaching Assistant Systems.

\subsection{Collaborative Learning}

Collaborative Learning is a term that refers to a set of pedagogical approaches that imply activities performed by students and instructors in a group manner. The students get involved in a work group integrated by two or more people. In these groups, the students can complete several activities such as research, problem solving, product creation, etc (Smith and Macgregor, 1992).

Additionally, the Collaborative Learning is known as Collaborative Work in the academic field (Dillenbourg, 1999). Besides, in specific conditions, the Collaborative Learning can be more effective than individual learning. However, sometimes identifying this type of conditions is not easy. For several authors as Webb (1991) and Dillenbourg (1999) there are some dependent and independent variables associated with Collaborative Learning. For instance, as Dillenbourg et al. (1996) Collaborative Learning is more effective than individual learning when the following conditions are met: i) Group heterogeneity, ii) Individual prerequisites and iii) Task features (Dillenbourg et al., 1996)theories of collaborative learning tended to focus on how individuals function in a group. More recently, the focus has shifted so that the group itself has become the unit of analysis. In terms of empirical research, the initial goal was to establish whether and under what circumstances collaborative learning was more effective than learning alone. Researchers controlled several independent variables (size of the group, composition of the group, nature of the task, communication media, and so on. In this sense, it is necessary to combine the mentioned variables to warrant the effectiveness of Collaborative Learning. This can allow the student-to-student interactions when they participate in a work group. The nature of these interactions provides meaningful learning results (Webb, 1991).

\subsection{Computer Supported Collaborati-} ve Learning

Computer Supported Collaborative Learning (CSCL) is a paradigm influenced by a set of social sciences approaches as the socio constructivist theory by Piaget; the social cultural theory by Vygotsky and socio cognitive models (Echeverría, 2011). As Dillenbourg and Traum (1999), CSCL focuses on how technology supported collaborative learning can enhance the students' interactions into the work groups. Besides, he argues that the collaboration and technology relevance can help the members of a community to share knowledge and useful experiences (Ploetzner et al., 1999). In this context, there are several elements associated with CSCL: the collaborative learning, the learning results and the technological resources.

As several research studies performed by (Smith and Macgregor, 1992; Dillenbourg et al., 1996) and (Koschmann, 2008), the CSCL environments have advantages in the educational context from both learning methods viewpoints and the nature of the student-to-student interactions. Some of the most important advantages are presented as follows: 
- The collaboration can be supported by different learning approaches and applications.

- The implementation of the CSCL environments and their usefulness through Internet foster the student-to-student interaction anywhere and anytime.

- The students and the instructors play new roles and they acquire new responsibilities compared to traditional learning methods. The instructor is a facilitator of the teachinglearning processes and the students participate actively and they are in charge of their own learning process.

- $\quad$ The shared workspaces and the distributed interactions offer multiple learning perspectives for the students. Under these circumstances they can acquire a variety of knowledge and competencies.

As a result of the completed research studies in the CSCL field, a great amount of environments have been developed to support several collaborative learning activities (Dillenbourg, 1999; Echeverría, 2011) and (Risko et al., 2013).

\subsection{Learning Management Systems}

The Learning Management Systems (LMS) support the teaching-learning processes and they play an important role in the academic field (Costa, Alvelos and Teixeira, 2012). These systems are recognized worldwide and they contain a set of tools for content, users, communication and assessment management (Villegas and Carrillo, 2011). Several of these systems are for commercial use and others are for free use and open source. Among the LMS best known are Blackboard (Blackboard, 2015), Claroline (Claroline, 2015), Dokeos (Dokeos, 2015), Moodle (Moodle, 2015) and Sakai (Sakai, 2018). These systems are of general purpose and are being used by both high schools and universities around the world. The main usages of these systems are: for the design of web based courses, for the support of the studentto-instructor and the student-to-student interactions.
Besides, LMS are comprised by several services to support monitoring and evaluation processes. In a simple and easy way, in these LMS's we can find many resources and learning activities for designing courses and providing support to users.

The LMS's have different features and capabilities to support e-learning. These are organized as Ajlan and Zedan (2008) into three categories: i) Learner Tools, ii) Support Tools and iii) Technical Specifications Tools. The Learner Tools contain Communication, Productivity and Student Involvement Tools. The Support Tools contain Administration, Course Delivery, and Content Development Tools. Finally, the Technical Specifications Tools Contain Hardware/Software and Pricing/Licensing tools. Based on the aforementioned features and capabilities, several comparative studies between different LMS's have been made. In this context, we can mention the studies performed by (Al-Ajlan and Zedan, 2008; Kumar, Gankotiya and Dutta, 2011). The results of these studies show that Moodle is one of the most used and recognized LMS's.

\subsection{Teaching Assistant Systems}

The Teaching Assistant Systems (TAS) are dedicated to both students and instructors. The Intelligent Teaching Assistant Systems (ITAs) as Lesta and Yacef (2002) are a type of Intelligent Tutoring System (ITS) that support educational or training processes in an intelligent manner. ITAs support instructors in their tasks as well as help the students in their learning processes. An ITA can provide assistance in the areas such as pedagogy, monitoring, analysis and synthesis of learning results. In this context some of the most relevant features supported by an ITA are:

- Learning diagnosis and assessment.

- Generating customized material for a particular student.

- Monitoring students during the execution of an excercise.

- Result analysis or synthesis 


\section{- $\quad$ ITS creation and/or definition}

Additional to the features mentioned before, there are two dimensions associated with an ITA: reducing the quantity or the length of burdensome tasks that can be automated and improving the quality of the teaching process by providing new or better tools and feedback to the instructor (Lesta and Yacef, 2002).

Both TAS and ITAs are integrated by several tools that allow to organize the students and the instructors workspace. In this context, several research studies about TAS and ITAs can be found. For instance the Logic-ITA which is a web-based Intelligent Teaching Assistant system used within the School of Information Technologies at the University of Sydney (Abraham and Yacef, 2002; Yacef, 2005). Pelican, which is an e-learning platform used as a tool to design collaborative learning scenarios (Vélez, 2009). SIgMa is an adaptable feedback generation tool for instructors, students and the e-learning platforms (Martín et al., 2008). PETCHA is a Teaching Assistant used in computer programming courses. This tool helps the instructors to design programming exercises and the students to solve these types of excercises (Queirós and Leal, 2012). In addition, a Virtual Assistant Architecture to support the delivery of texts in language teaching-learning processes is presented in (Rivera and Machuca, 2014). This
Assistant performs functions to support the student in the process of text production. Besides, it provides for writing and grammatical assistance. Finally, in another research study, two teaching assistant tools embedded into the NLtoFOL system are described. The first tool is a teaching material manager and the second one is a teaching data analyser (Perikos, Grivokostopoulou and Hatzilygeroudis, 2011).

All the learning environments mentioned in this paper have been relevant to the review related work to our approach and for the implemention of the TASystem presented in this research study.

\section{Teaching Assistant System-Tasystem}

The TASystem (Echeverria, 2017) is a platform developed by supporting the design of the collaborative learning activities into the LMS Moodle. The TASystem is composed by three interconnected tools as follows: i) The Task Manager, ii) The Assessment Manager and iii) The Report Manager (Echeverría et al., 2017). The Figure 1 presents a screenshot with the TASystem in Moodle.

The TASystem was implemented by developing a block plugin. This block was integrated into the LMS Moodle. For the development of the block plugin, a General Architecture based on components was proposed.

Figure 1. Screenshot with the TASystem in LMS Moodle

\section{Programming Course}

Phase 1: Definition of the students' proposal to solve an assigned problem 응

Phase 2: Design of the solution

응

Phase 3: Implementation of the algorithm and final lectures

응

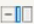

Teaching Assistant System

ㄱ. Task Manager

를 Assessment Manager

idi. Report Manager 
This allowed for the block to be integrated by three main components as Moodle Activity Modules: i) the Task Module, ii) the Assessment Module and iii) the Report Module. The Figure 2 shows the General Architecture of the TASystem.

Figure 2. The General Architecture of the TASystem (Echeverría, Cobos and Buendía, 2013)

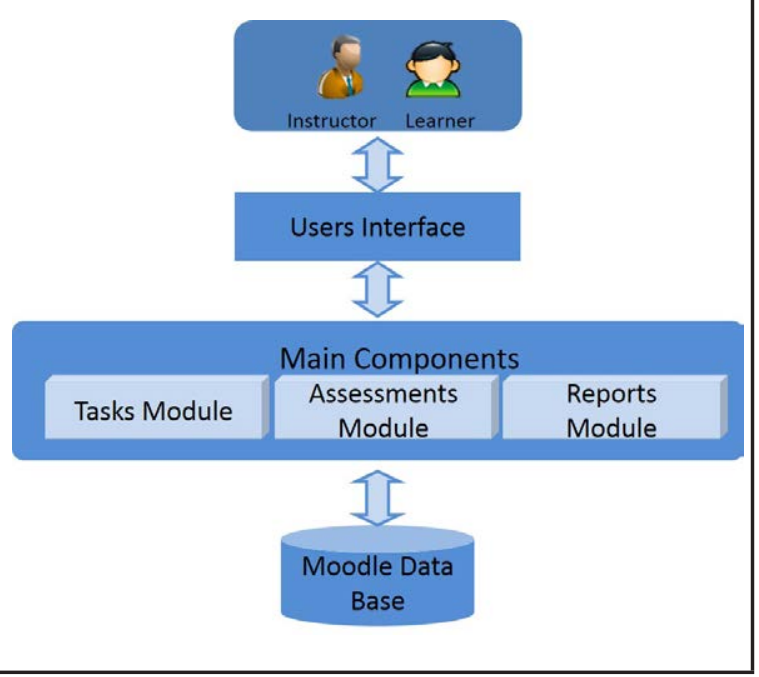

Detailed information about the TASystem General Architecture description and its components can be found in (Echeverría, Cobos and Morales, 2013; Echeverria, 2017).

With the aim to integrate the mentioned modules to the Moodle database, one data model was created. This model and the general architecture of the TASystem allow using these modules individually. The Figure 3 presents the data model of the assistant as an UML (Unified Model Language) entity-relationship diagram. This model contains five interconnected entities: User, Scenario, Grade, Learning Activity and Evaluation.

As we mentioned in the section related to the description of the TASystem, this assistant is composed by three interconnected tools. These tools can be used by the instructors. The Figure 4 shows a screenshot with the instructor's view of the assistant's Task Manager tool in Moodle.

In the student's view, two tools of the TASystem can be used by the students: the Assessment Manager and the Report Manager. The Figure 5 shows a screenshot with the student's view of the assistant's Assessment Manager tool in Moodle.

\section{Figure 3. The data model of the TASystem}

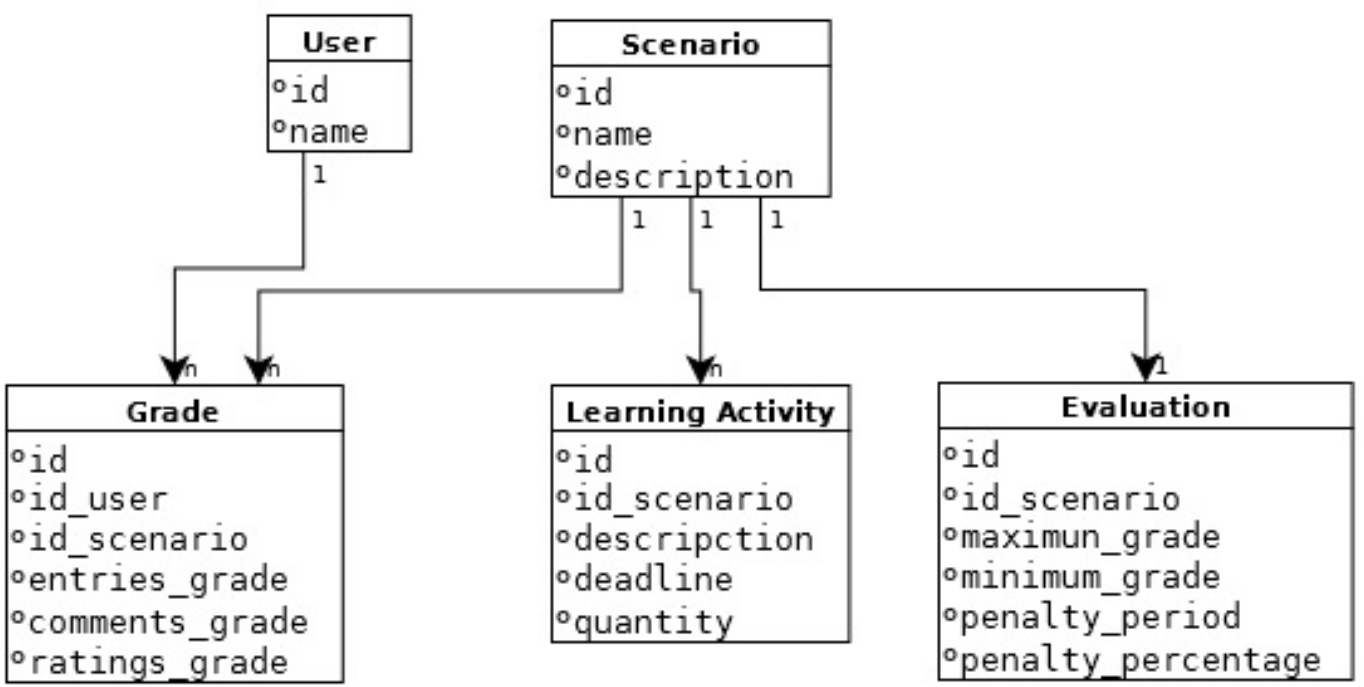


Figure 4. Screenshot with the instructor's view of the Task Manager tool

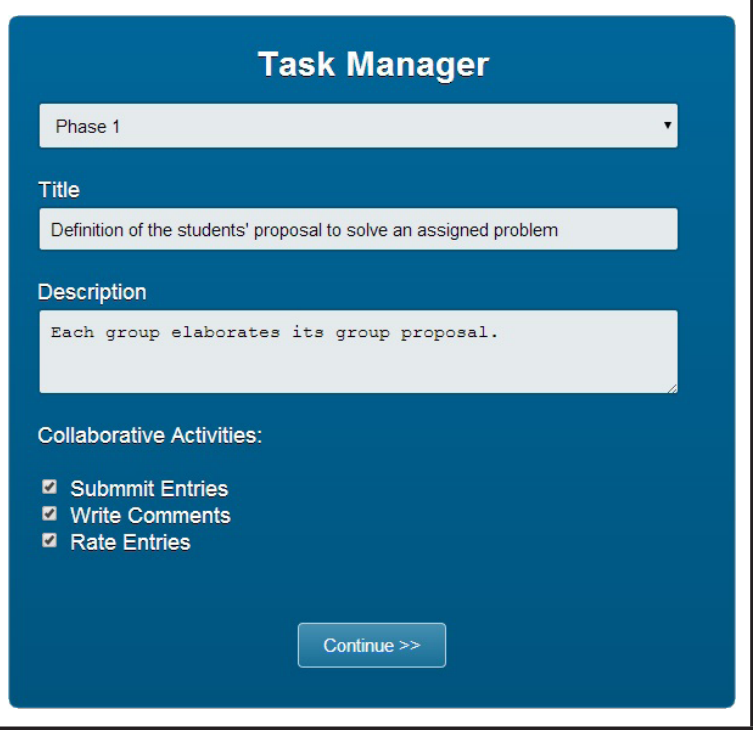

\section{Research Methodology}

This section deals with the research objectives and the hypothesis, the participants, the procedure and the instruments of the research study.

\subsection{Research objectives and hypothesis}

For carrying out the research study presented in this paper two objectives were established. Each objective had a research hypothesis ( $\mathrm{H} 1$ and $\mathrm{H} 2)$ as follows:

Objective1: to analyze the student-to-student interactions when they collaborate in small group level and when they collaborate in class group level.

H1: The student-to-student interactions supported by a Teaching Assistant System-TASystem when they per-form collaborative learning activities in small group level are greater than the student-tostudent interactions when they completed the same activities in class group level.

Objective2: to know the students' satisfaction level associated with the use of the TASystem in Moodle.

H2: The students that used the services from the Teaching Assistant System-TASystem felt satisfied with the help of the assistant in the Collaborative Lab Project.

\subsection{Participants}

Fifty-four students in total participated in the Collaborative Lab Project as part of the Programming course (Echeverría et al., 2017). The students were organized in 18 groups of three members. However, only 14 groups of students participated actively in the collaborative learning scenarios. For this reason, in the current paper are showed the obtained results from forty two students.

Figure 5. Screenshot with the student's view of the Assessment Manager tool

Phase 1: Definition of the students' proposal to solve an assigned problem

Description Each group elaborates its group proposal.

Collaborative Activities:

SUBMMIT ENTRIES:
Description

The group leader submmits the group proposal

\section{The evaluation criteria}

Minimum grade: 

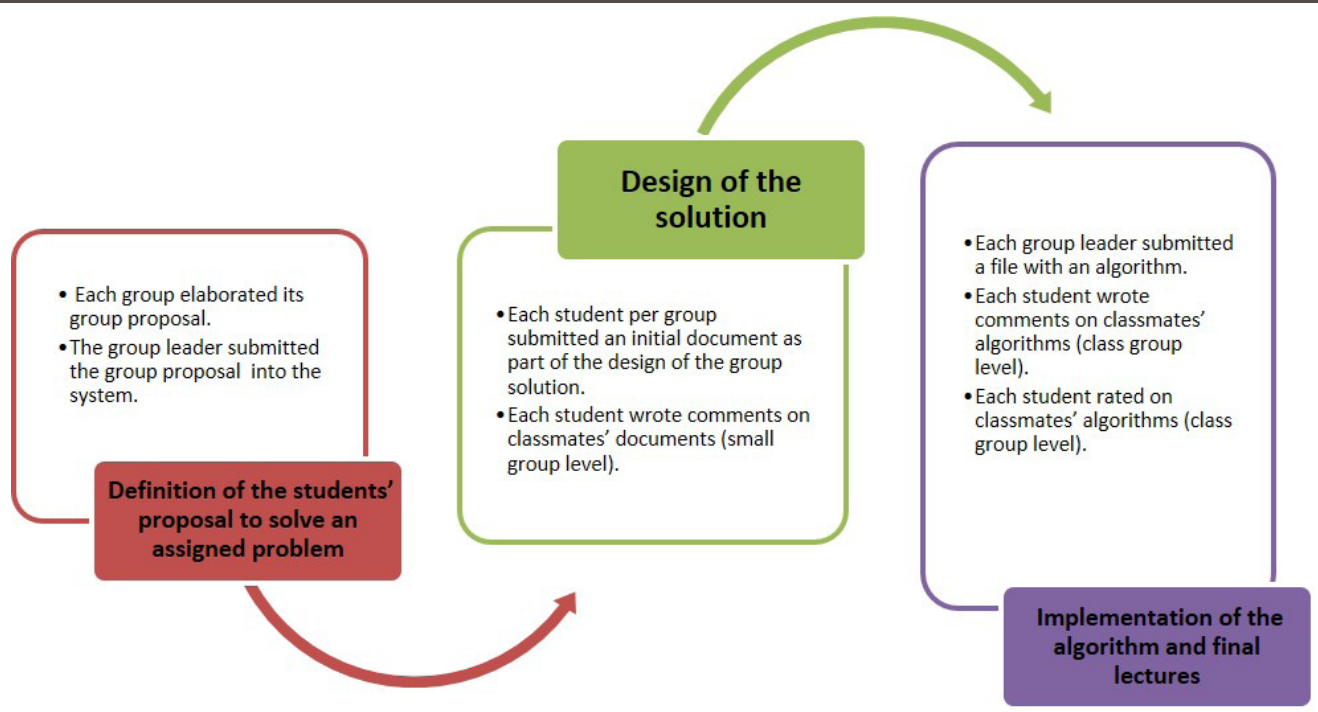

\subsection{Procedure}

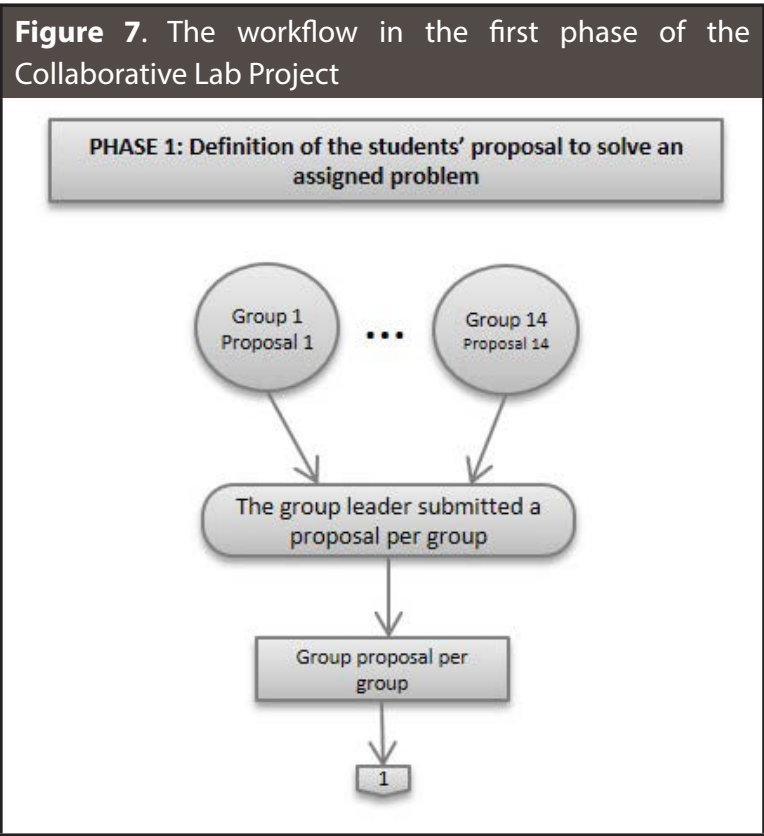

During the Collaborative Lab Project the students were organized in groups and they had to participate in three collaborative learning scenarios: 1) Definition of the students' proposal to solve an assigned problem, 2) Solution design and 3) Implementation of the algorithm and final presentations. The Figure 6 presents the workflow in the Collaborative Lab Project.

\section{Figure 8. The workflow in the second phase of the} Collaborative Lab Project

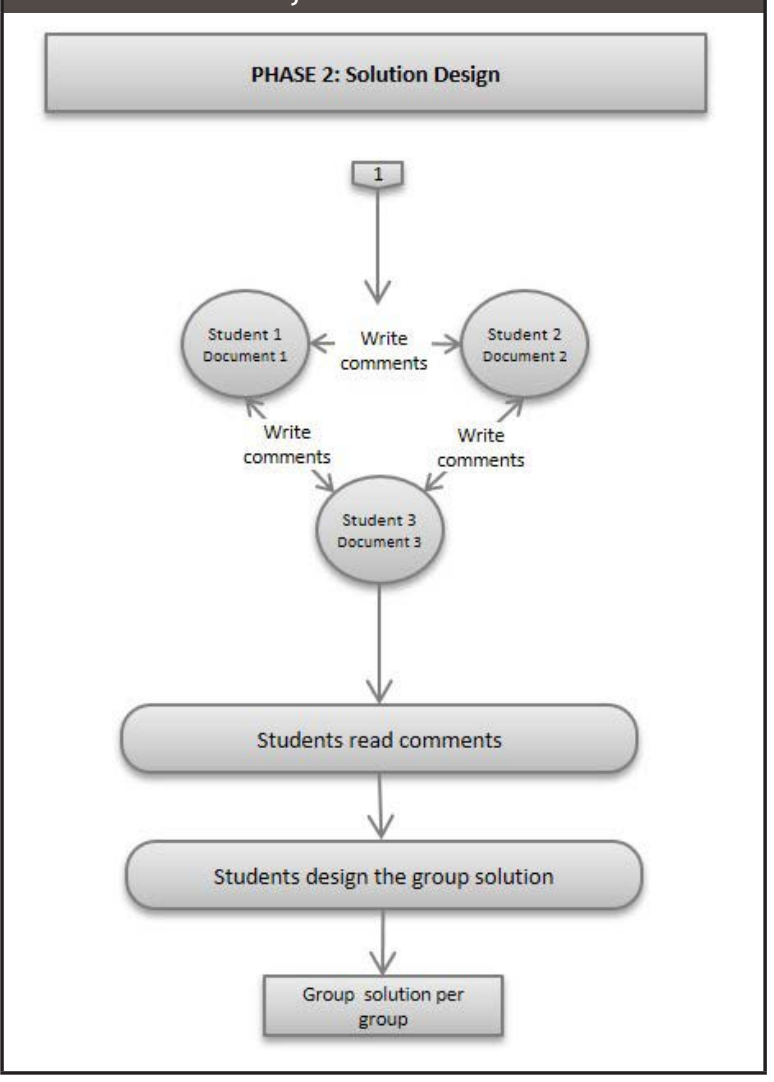


In the first phase, the group proposals were obtained (See Figure $\mathbf{7}$ for details).

The Figure 8 presents the workflow in the second phase (small group level) of the Collaborative Lab Project. Fourteen group solutions were designed by the students in this phase.

The Figure 9 presents the workflow in the last phase of the Collaborative Lab Project.

Figure 9. The workflow in the third phase of the Collaborative Lab Project

PHASE 3: Implementation of the algorithm and final presentations
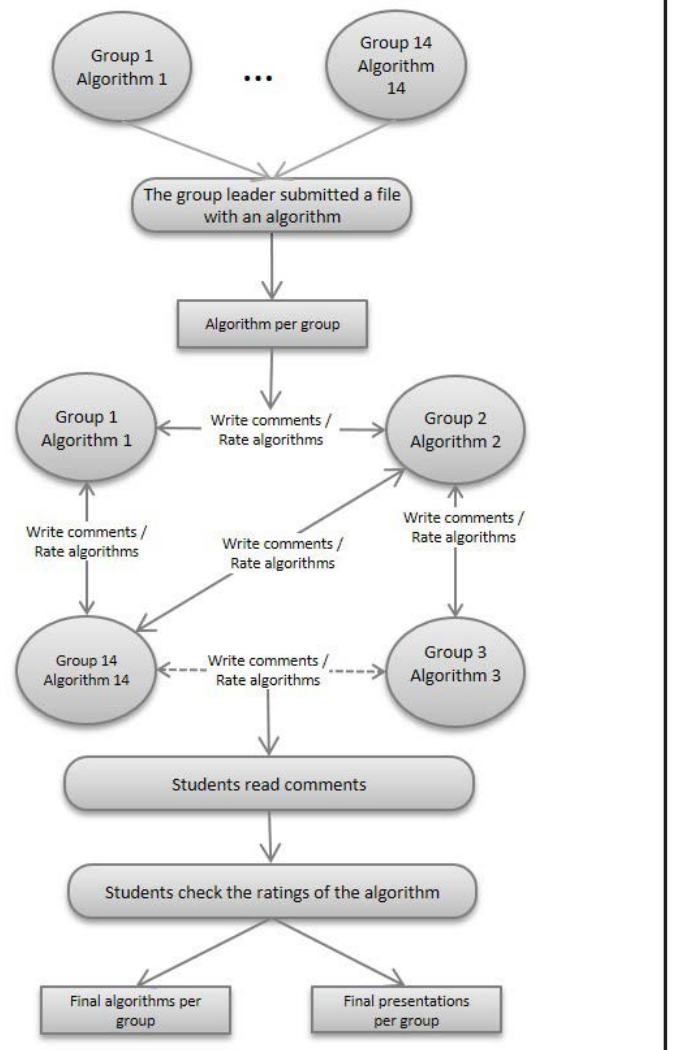

\subsection{Instruments}

In this research study, on one hand, the student-to-student interactions were analyzed. These interactions were associated with the dependent variables recorded in the LMS Moodle. These dependent variables were:
V1: submitted comments by the students to other classmates' entries when they performed collaborative learning activities at a small group level.

V2: submitted comments by the students to other classmates' entries from another groups when they performed collaborative learning activities at a class group level.

These data allowed us to examine the active participation of the students in the learning activities executed in the two mentioned levels of collaboration.

Besides, one individual questionnaire was applied to the students who participated in this study. The aim of the questionnaire was to know the students' satisfaction level when completing the learning activities in the Collaborative Lab Project. These levels were related to three following elements:

E1: The access to the TASystem embedded in Moodle

E2: The TASystem Graphic User Interface Design

E3: The TASystem tools support

\section{Results and Discussion}

The collected quantitative data in this research study consisted of, first, the values of the dependent variables (V1 and V2) recorded in the LMS Moodle; and second, the students' responses to the questionnaire related to the students' satisfaction when completing the learning activities in the Collaborative Lab Project.

The data related to V1 and V2 were examined using statistical analysis. 149 comments (V1 + V2) in total were submitted by the students. Two types of comments were written by the students: i) comments about the knowledge related to programming, computational thinking or topography concepts (comments in context) and ii) comments about other topics (comments out of context). As (Van Boxtel, Van der Linden and Kanselaar, 2000) the 
conceptual understanding indicates the manner how the students perform learning activities that demand the use of the concepts. In this context, the students must be able to use concepts to describe, explain and manipulate phenomena in a specific domain. In our research study, we have considered the possible influence of conceptual knowledge used by the students to improve their documents as part of the group solution design and their files corresponding to the final algorithms.

In this sense, two types of analysis were made with the purpose of knowing the students' conceptual knowledge from their interactions to the submitted comment contents. In the first analysis, the comments in context were examined when the students performed collaborative learning activities in small group level. And, in the second one, the same type of comments were analysed when the students participated in class group level.

\section{Results of the first analysis}

Eighty four comments were written by the students when they participated in small groups. The maximum number of comments wrote in small group level was 16 . These comments were made in the G6 work group. And the minimum number of comments that were written was 1 . These comments were made in the G5 work group. Into the work groups: G2, G6 and G1, the students participated in an active manner. In these groups they wrote large of comments. Fifteen comments were submitted by the students from G2 group, sixteen comments by students from G6 group and twelve by the students from G1group (See Figure 10).

From our point of view, the student-to-student interactions in small group level were good. And this could have a positive influence in the students' learning process. Specifically, the collaborative construction of the group solution could be improved. Several research studies have corroborated that it is possible to build up knowledge collaboratively from the students' annotations contributions when they participate in learning environments (Diez and Cobos, 2008; Pifarre and Cobos, 2010).

The $79,8 \%$ of the comments submitted by the students were comments in context. In our opinion, the students' active participation impacted the collaborative creation of the documents about the group solution. To be precise, six group solutions obtained the highest grades. These solutions corresponded to documents with high quality.

\section{Figure 10. Comments written by the students in small and class group level}

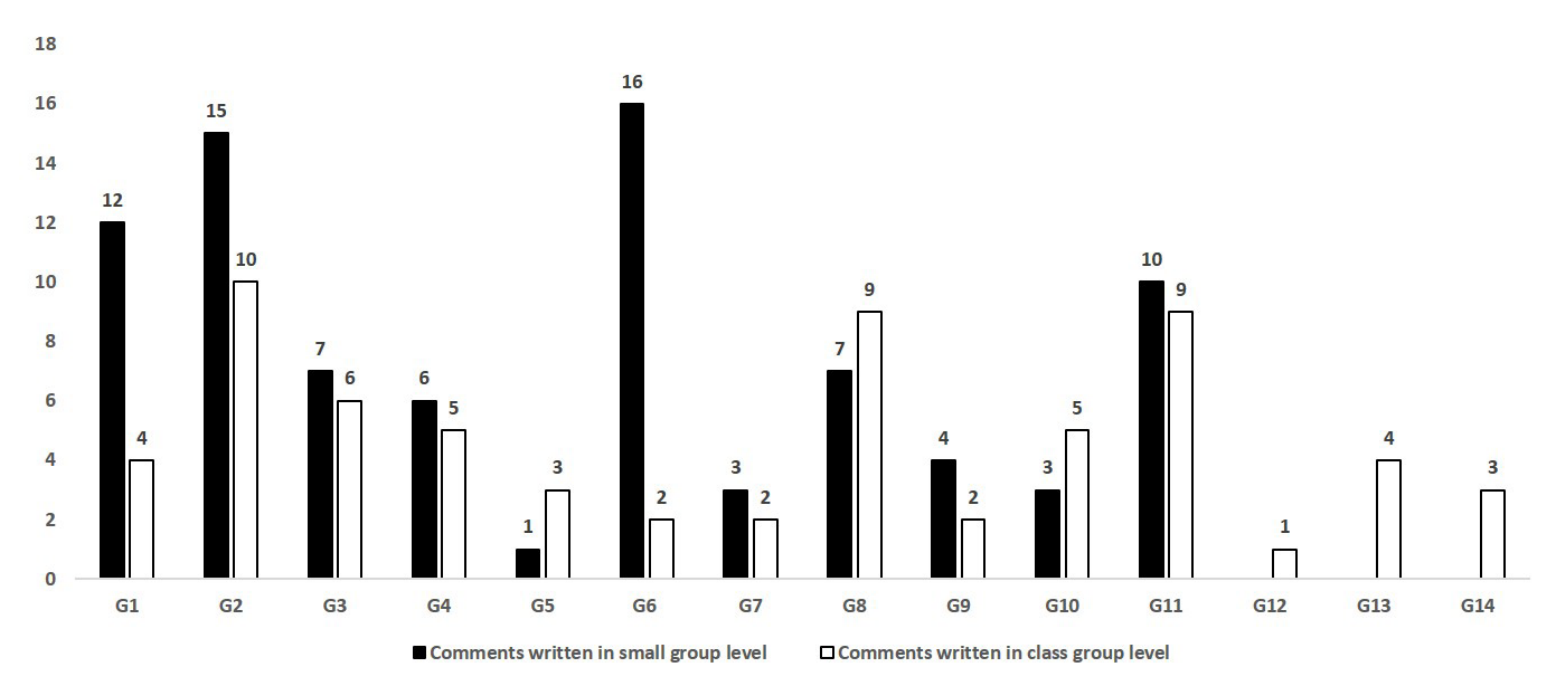


Figure 11. The students' satisfaction levels

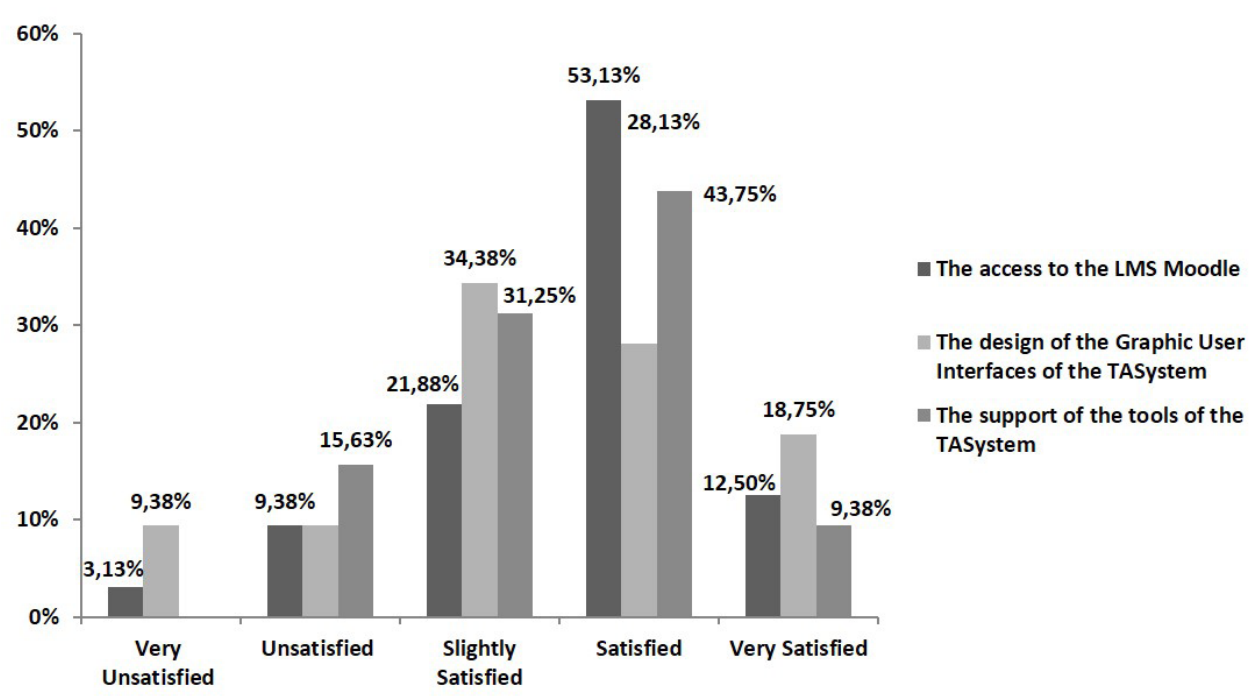

\section{Results of the second anallysis}

Sixty five comments were written by the students when they participated in class groups. The maximum number of comments written in class group level was 10. These comments were made by students from the G2 work group. Only one comment was written into the G12 group. Students who belonged to the work groups G2, G8 and G11 participated in an active manner. Ten comments were submitted by students from G2 group and nine comments by students from G8 and G11 groups. The Figure 10 presents the results of the comments wrote by the students in both collaborative levels.

The $87,69 \%$ of the comments submitted by the students were comments in context. From our point of view, the comments posted by the students about their fellow classmates' documents on one hand, helped to improve the group solutions elaborated in small group level; and, on the other hand, this activity helped to enhance the final algorithms. In this context, the six groups that obtained the highest grades at a small group level continued with high grades in class group level. These grades were obtained in the final algorithms.
Theother fourgroups improved theirdocuments (group solution and final algorithms). These students elaborated a new version of the documents about the group solutions and they submitted the documents into the system. The instructor's opinion was that this exercise allowed the students to gather documents with better quality.

Besides, the students took into account the comments in context in order to improve the files corresponding to the final algorithms. As a consequence, these students increased their grades in class group level.

These results allow us to conclude that the students felt motivated to write comments in context in both small and class group level. This encouraged the students to actively participate and to create documents with high quality during the lab project.

With the aim to continue with the collected data analysis, which is presented in Figure 10; the Wilcoxon rank sum test was done in order to check the difference in samples from the two types of student-to-student interactions. The result of this test showed that the total number of comments written by the students in small groups level (V1) had statistical significance with respect to the total 
number of comments written between students in class group level (V2).

The Wilcoxon rank sum test confirmed us that the outcomes of the two type of interactions were statistically different from each other ( $p$-value $=$ 0.001444).

This allowed us to conclude that the students were more motivated to interact with fellow classmates who belonged to the same work group (small group level). Especially when they wrote comments on classmates' entries.

The results of the individual questionnaires answered by the students showed that the maximum levels of the students' satisfaction were: satisfied and slightly satisfied. On one hand, 53,13\% and the $43,75 \%$ of the students felt satisfied with the access to the TASystem embedded into the LMS Moodle and the TASystem tools support respectively. On the other hand, $34,38 \%$ of the students felt slightly satisfied with the TASystem graphic user interface design. This led us to conclude that most of the students felt pleased using the TASystem into the LMS Moodle. The Figure 11 presents the results of the students' satisfaction level.

\section{Conclusions and Future Work}

In this paper, we have outlined the analysis of the students' interactions and satisfaction in a Collaborative Lab Project supported by a Teaching Assistant System called TASystem. This assistant is a platform developed at University Autónoma of Madrid to support instructors in the design of collaborative learning activities and to help the students to perform these activities in LMS. The TASystem was embedded into the LMS Moodle. And this assistant contained three tools: i) The Task Manager, ii) The Assessment Manager and iii) The Report Manager.

A research study was presented in this paper. This study was based in a research methodology. Forty two students from the School of Engineering at the Universidad del Valle-UNIVALLE (Colombia) took part in the Collaborative Lab Project. This project was based on the design and the implementation of an algorithm. The instructor used the TASystem to design three phases to support the Lab Project: i) Definition of the students' proposal to solve an assigned problem, ii) Solution design and iii) Implementation of the algorithm and final presentations. The students completed collaborative learning activities on each phase. Each phase was a Collaborative Scenario.

In order to analyze the research study presented in this paper, two research objectives were defined: i) to analyze the student-to-student interactions when they collaborate in both small and class group levels and ii) to know the students' satisfaction levels associated with the use of the TASystem in Moodle.

To accomplish the first objective, two types of analysis were made to know the students' conceptual knowledge from their interactions to the content of submitted comments. In this context, both in small and class group levels, the students wrote two types of comments: i) comments about knowledge related to programming, computational thinking or topography concepts (comments in context) and ii) comments about other topics (comments out of context).

The results showed that, in small group level, $79,8 \%$ of the comments written by the students were comments in context. Likewise, $87,69 \%$ of the comments written by them in class group level were comments in context. It is important to note that throughout the time that this study took place, the students were submitting comments that were more in context.

Additionally, we have deliberated about how the conceptual knowledge acquired by the students helped them with improving the quality of the documents that they submitted into the system. The students' conceptual knowledge was examined from the analysis of the student-to-student interactions to the content of their submitted comments. We highlighted that the students improved their 
submitted documents after they read the comments written by their fellow classmates.

The positive results obtained from this study allow us to conclude that the students felt stimulated to elaborate conceptual knowledge in a collaborative manner. This was verified from the analysis of the contents of the comments in context submitted by the students in both small and class group levels. Besides, the elaboration of the documents with high quality was corroborated. Furthermore, the students improved their performance when they participated in class group level. To be precise, they increased the grades obtained in small group level.

Besides, the Wilcoxon rank sum test was applied to analyze the collected data from the dependent variables associated with the first objective. In this case, the results showed that the students were encouraged to interact with their classmates who belonged to the same work group that is, when they collaborate in small group level. Specifically, when the students wrote comments on classmates' entries.

With the aim to achieve the second research objective defined in this study, a questionnaire was applied to the students in order to know the students' satisfaction level when performing the activities in the Collaborative Lab Project. These levels were related to: i) the access to the TASystem embedded into the LMS Moodle, ii) TASystem graphic user interface design and iii) The TASystem tools support. The results of the questionnaire showed that most of the students felt satisfied when they used the TASystem in Moodle.

As a future work, we propose on one hand, to improve the implementation of the TASystem. In this context, we will study the assistant tools usability features. This study will allow us to improve the TASystem graphical user interface design. Besides, we will try to assess the development of other types of knowledge supported by TASystem.

Finally, even though the TASystem was embedded in the LMS Moodle, we propose that this assistant be integrated to MOOC (Massive Online Open Courses) platforms.

\section{Acknowledgment}

This research was partly funded by the Spanish National Plan of $\mathrm{R}+\mathrm{D}$, project number TIN201124139; and by the Autonomous Community of Madrid, e-Madrid project, number S2013/ICE2715; and "Carolina Foundation" scholarship.

\section{References}

Abraham, D. and Yacef, K. (2002) 'Adaptation in the Webbased Logic-ITA', Lecture Notes in Computer Science (including subseries Lecture Notes in Artificial Intelligence and Lecture Notes in Bioinformatics), 2347, pp. 456-461. Available at: https://www. scopus.com/inward/record.uri?eid=2-s2.078549275573\&partnerID $=40 \& m d 5=a 372 e 0 d 7 c 4 c$ eee9ef76db65b5a5bf2b6.

Al-Ajlan, A. and Zedan, H. (2008) 'Why Moodle', 2008 12th IEEE International Workshop on Future Trends of Distributed Computing Systems, pp. 58-64. doi: 10.1109/FTDCS.2008.22.

Blackboard (2015). Available at: http://es.blackboard. com/sites/international/globalmaster/ (Accessed: 1 January 2015).

Van Boxtel, C., Van der Linden, J. and Kanselaar, G. (2000) 'Collaborative learning tasks and the elaboration of conceptual knowledge', Learning and Instruction, 10(4), pp. 311-330. doi: 10.1016/S09594752(00)00002-5.

Claroline (2015). Available at: http://www.claroline.net/ (Accessed: 1 January 2015).

Claros, I. et al. (2014) 'Towards a Collaborative Pedagogical Model in MOOCs', in 2014 IEEE Global Engineering Education Conference (EDUCON), pp. 905-911.

Claros, I., Echeverria, L. and Cobos, R. (2015) 'Towards MOOCs scenaries based on collaborative learning approaches', in Global Engineering Education Conference (EDUCON), 2015 IEEE, pp. 989-992. doi: 10.1109/EDUCON.2015.7096093.

Costa, C., Alvelos, H. and Teixeira, L. (2012) 'The Use of Moodle e-learning Platform: A Study in a Portuguese 
University', Procedia Technology, 5, pp. 334-343. doi: 10.1016/j.protcy.2012.09.037.

Diez, F. and Cobos, R. (2008) 'A case study of a cooperative learning experiment in Artificial Intelligence', Computer Applications in Engineering Education, 15(4), pp. 308-316. doi: 10.1002/cae.20114.

Dillenbourg, P. et al. (1996) 'The evolution of research on collaborative learning', Learning, pp. 189-211. Available at: http://citeseerx.ist.psu.edu/viewdoc/ download?doi=10.1.1.92.2555\&amp;rep=rep1\&am p;type=pdf.

Dillenbourg, P. (1999) 'What do you mean by â€ $€^{\mathrm{TM}}$ collaborative learning '?', Collaborative learning Cognitive and computational approaches, 1(6), pp. 1-15. doi: 10.1.1.167.4896.

Dokeos (2015). Available at: http://www.dokeos.com/ (Accessed: 12 June 2017).

Echeverria, L. (2017) UNA PROPUESTA DE UNA PLATAFORMA DE APRENDIZAJE BASADA EN ESCENARIOS COLABORATIVOS PARA LA REALIZACIÓN DE EXPERIENCIAS DE APRENDIZAJE MIXTO CON SOPORTE A LA INVESTIGACIÓN, TeSiS doctoral. Universidad Autónoma de Madrid.

Echeverría, L. (2011) Motivation Booster based on the monitoring of users' progress in collaborative learning scenarios. Trabajo Fin de Master, Universidad Autónoma de Madrid.

Echeverría, L. et al. (2017) 'Using collaborative learning scenarios to teach programming to non-CS majors', Computer applications in engineering education, 25(3), pp. 1-13.

Echeverría, L. and Cobos, R. (2015) 'Designing the assessment of the collaborative learning process in LMS courses', in Proceedings of the 2015 IEEE 19th International Conference on Computer Supported Cooperative Work in Design (CSCWD), pp. 218-223.

Echeverría, L., Cobos, R. and Buendía, S. (2013) 'A Teaching Assistant for task and assessment management in Collaborative Learning Scenarios', in Octavo Congreso Colombiano de Computación-8CCC 2013, pp. 26-29.

Echeverría, L., Cobos, R. and Morales, M. (2013) ‘Designing and evaluating collaborative learning scenarios in Moodle LMS Courses', in Proceedings of the 10th International Conference on Cooperative Design, Visualization, and Engineering, pp. 61-66.
Koschmann, T. (2008) 'Paradigm shifts and instructional technology: An introduction', Radiologic technology, 80(1), pp. 67-74. Available at: http://www.ncbi. nlm.nih.gov/pubmed/23032751.

Kumar, S., Gankotiya, A. K. and Dutta, K. (2011) 'A comparative study of moodle with other e-learning systems', in ICECT 2011 - 2011 3rd International Conference on Electronics Computer Technology, pp. 414-418. doi: 10.1109/ICECTECH.2011.5942032.

Lesta, L. and Yacef, K. (2002) 'An intelligent teaching assistant system for Logic', Intelligent Tutoring Systems. Available at: http://link.springer.com/ chapter/10.1007/3-540-47987-2_45.

Martín, M. et al. (2008) 'Generating teacher adapted suggestions for improving distance educational systems with SIgMa', in Proceedings - The 8th IEEE International Conference on Advanced Learning Technologies, ICALT 2008, pp. 449-453. doi: 10.1109/ICALT.2008.227.

Moodle (2015). Available at: https://moodle.org/ (Accessed: 1 January 2015).

Perikos, I., Grivokostopoulou, F. and Hatzilygeroudis, I. (2011) 'TEACHING ASSISTANT TOOLS FOR NL TO FOL CONVERSION', in IADIS International Conference e-Learning, pp. 337-344.

Pifarre, M. and Cobos, R. (2010) 'Promoting metacognitive skills through peer scaffolding in a CSCL environment', International Journal of ComputerSupported Collaborative Learning, 5(2), pp. 237253. doi: 10.1007/s11412-010-9084-6.

Ploetzner, R. et al. (1999) 'Learning by Explaining to Oneself and to Others', Collaborative-learning; Cognitive and Computational Approaches, pp. 103121.

Queirós, R. and Leal, J. (2012) 'PETCHA: a programming exercises teaching assistant', Proc. ITiCSE 2012, pp. 192-197. doi: 10.1145/2325296.2325344.

Risko, E. F. et al. (2013) 'The collaborative lecture annotation system (CLAS): A new TOOL for distributed learning', IEEE Transactions on Learning Technologies, 6(1), pp. 4-13. doi: 10.1109/ TLT.2012.15.

Rivera, D. and Machuca, L. (2014) 'A Virtual Assistant Architecture to support the delivery of texts in languages teaching - learning processes', Ingeniería y Competitividad, 16(2), pp. 155-164. 
Sakai (2018). Available at: https://sakaiproject.org/ (Accessed: 12 July 2018).

Smith, L. and Macgregor, J. T. (1992) What is Collaborative Learning?, Collaborative Learning: A Sourcebook for Higher Education.

Vélez, J. (2009) Pelican. Una plataforma para el diseño y desarrollo de escenarios de aprendizaje colaborativo. Soporte a los aspectos dinámicos. Universidad Nacional de Educación a Distancia.

Villegas, L. E. M. and Carrillo, P. J. R. (2011) 'Experiences in developing an e-learning system for language learning and teaching', in 2011 6th Colombian Computing Congress (CCC). IEEE, pp. 1-6. doi: 10.1109/COLOMCC.2011.5936281.

Webb, N. M. (1991) 'Task-Related Verbal Interaction and Mathematics Learning in Small Groups', Journal for Research in Mathematics Education, 22(5), pp. 366389. doi: $10.2307 / 749186$.

Yacef, K. (2005) 'The Logic-ITA in the classroom: a medium scale experiment', International Journal of Artificial Intelligence in Education (IJAIED), 15(1), pp. 41-60. TO REFERENCE THIS ARTICLE / PARA CITAR ESTE ARTIGO /

Echeverría Rodríguez, L.; Cobos Pérez, R.; Machuca-Villegas, L. (2019). Analysis of the Students' Interactions and Satisfaction During a Collaborative Lab Project. Revista EIA, 16(31), enero-junio, pp. 209-223. [Online]. Disponible en: https:// doi.org/10.24050/reia.v16i31.1256 